\title{
Desulfovibrio tunisiensis sp. nov., a novel weakly halotolerant, sulfate-reducing bacterium isolated from exhaust water of a Tunisian oil refinery
}

Correspondence
Marc Labat
labat@esil.univmed.fr

Sulfate-reducing bacteria (SRB) cause great economic damage, particularly in the oil industry, owing to their ability to produce hydrogen sulfide. Crude oil that contains elevated amounts of hydrogen sulfide has reduced commercial value: the presence of hydrogen sulfide makes the separation of water from oil less efficient, and ferrous sulfide precipitates can clog drilling and pumping equipment (Cord-Ruwisch, 1985). In addition, the toxicity of hydrogen sulfide is an occupational health and safety hazard for workers. SRB are the most potent contributors to the anaerobic corrosion of metal, which causes costly failures of equipment and pipelines (Hamilton, 1985). An increasing number of species of SRB from oil wells and from oilfield production fluids are being investigated and

Abbreviation: SRB, sulfate-reducing bacteria.

The GenBank/EMBL/DDBJ accession number for the 16S rRNA gene sequence of strain RB22 ${ }^{\top}$ is EF577029. many mesophilic species of SRB from oilfields and production waters have been described in detail (Magot et al., 1992). There is thus a pressing need to investigate the bacterial communities of oil wells and oilfield production fluids in various geographical locations, in order to identify the complex processes that lead to adverse effects in the industrial environment, and to find a mean of controlling microbial growth (Dang et al., 1996; Ben Ali Gam et al., 2007). Species of the genus Desulfovibrio have been isolated frequently from marine environments, including Desulfovibrio frigidus (Vandieken et al., 2006), Desulfovibrio alkalitolerans (Abildgaard et al., 2006), Desulfovibrio bizertensis (Haouari et al., 2006) and Desulfovibrio inopinatus (Reichenbecher \& Schink, 1997). Halotolerant to halophilic Desulfovibrio species have also been recovered from oilfield environments (Birkeland, 2005). These include Desulfovibrio vietnamensis (Dang et al., 1996) and Desulfovibrio longus (Magot et al., 1992), considered as 
halotolerant, and Desulfovibrio marinus (Ben Dhia-Thabet et al., 2007), Desulfovibrio bastinii (Magot et al., 2004), 'Desulfovibrio capillatus' (Miranda-Tello et al., 2003), Desulfovibrio indonesiensis (Feio et al., 1998, 2004) and Desulfovibrio gabonensis (Tardy-Jacquenod et al., 1996), considered as moderate halophiles.

In the present study, we undertook microbiological studies to isolate SRB that can tolerate crude oil in the culture medium, obtained from various exhaust waters of a Tunisian oil refinery located at Bizerte (Tunisia). Only members of the genus Desulfovibrio were isolated. One of these organisms, isolated from exhaust water of the oil refinery, was designated strain $\mathrm{RB} 22^{\mathrm{T}}$, and is proposed to represent a novel species of the genus Desulfovibrio.

Samples were collected in sterile glass bottles and stored in the dark at $4{ }^{\circ} \mathrm{C}$ until used. Nine strains were isolated from enrichment cultures initiated with crude oil and lactate under either sulfate or thiosulfate reduction conditions. The Hungate technique (Hungate, 1969) was then used throughout for cultivation. The enrichment medium contained (per litre distilled water): $30 \mathrm{~g} \mathrm{NaCl}, 0.3 \mathrm{~g}$ $\mathrm{KH}_{2} \mathrm{PO}_{4}, 0.3 \mathrm{~g} \mathrm{~K}_{2} \mathrm{HPO}_{4}, 1 \mathrm{~g} \mathrm{NH} \mathrm{NH}_{4} \mathrm{Cl}, 0.5 \mathrm{~g} \mathrm{MgCl}_{2} .6 \mathrm{H}_{2} \mathrm{O}$, $0.2 \mathrm{~g} \mathrm{CaCl}_{2}, 1 \mathrm{~g}$ yeast extract, $1 \mathrm{~g}$ peptone, $1 \mathrm{~g}$ cysteine hydrochloride (all w/v), $10 \mathrm{ml}$ trace element solution (Balch et al., 1979) and $1 \mathrm{ml} 0.1 \%(\mathrm{w} / \mathrm{v})$ resazurin; the $\mathrm{pH}$ was adjusted to 7.2 with $10 \mathrm{M} \mathrm{KOH}$ solution. The enrichment medium was boiled under a stream of $\mathrm{O}_{2}$-free $\mathrm{N}_{2}$ gas and cooled to room temperature and $4.5 \mathrm{ml}$ aliquots were distributed in Hungate tubes under a stream of $\mathrm{O}_{2}$-free $\mathrm{N}_{2}$ gas. The $\mathrm{N}_{2}$ gas phase was replaced by $\mathrm{N}_{2} / \mathrm{CO}_{2}(80: 20$, v/v) and the tubes were autoclaved for $21 \mathrm{~min}$ at $121{ }^{\circ} \mathrm{C}$. Before inoculation, $0.1 \mathrm{ml} 2 \%(\mathrm{w} / \mathrm{v}) \mathrm{Na}_{2} \mathrm{~S} .9 \mathrm{H}_{2} \mathrm{O}, 0.1 \mathrm{ml} 10 \%$ $(\mathrm{w} / \mathrm{v}) \mathrm{NaHCO}_{3}$ and $1 \%(\mathrm{v} / \mathrm{v})$ crude oil were added.

Enrichments were performed in Hungate tubes containing $4.5 \mathrm{ml}$ enrichment medium and were inoculated with water samples. Lactate and either sulfate or thiosulfate were added at $20 \mathrm{mM}$ before inoculation. The tubes were incubated at $30{ }^{\circ} \mathrm{C}$ for 1 week. Four enrichment series were performed. Cultures were purified by repeated use of the Hungate roll-tube method, using enrichment medium without crude oil and solidified with $2 \%(\mathrm{w} / \mathrm{v})$ agar (Difco). Several colonies were picked and cultured in the corresponding culture medium. The process of isolation was repeated several times until the isolates were deemed to be axenic. Growth was determined by inserting culture tubes directly into a model Cary 50 Scan spectrophotometer (Varian) and measuring the $\mathrm{OD}_{580}$. Sulfide was assayed photometrically as colloidal CuS according to the method of Cord-Ruwisch (1985). Desulfovibrio halophilus DSM $5663^{\mathrm{T}}$ and 'Desulfovibrio brasiliensis' DSM 15816 were obtained from the Deutsche Sammlung von Mikroorganismen und Zellkulturen (DSMZ; Braunschweig, Germany) and cultivated according to the procedures recommended by the DSMZ.

DNA was extracted from various isolates, including strain $\mathrm{RB} 22^{\mathrm{T}}$, according to the protocol described for the Wizard
Genomic DNA purification kit (Promega). The 16S rRNA genes of these isolates, including strain $\mathrm{RB}_{2} 2^{\mathrm{T}}$, were amplified using primers Fd1 (5'-AGAGTTTGATCCTGGCTCAG-3') and 1525R (5'-AAGGAGGTGATCCAGCC$\left.3^{\prime}\right)$ and with the following reaction conditions: $1 \mathrm{~min}$ at $96{ }^{\circ} \mathrm{C}, 30$ cycles of $20 \mathrm{~s}$ at $96{ }^{\circ} \mathrm{C}, 30 \mathrm{~s}$ at $55^{\circ} \mathrm{C}$ and $2 \mathrm{~min}$ at $72{ }^{\circ} \mathrm{C}$, with a final elongation step for $5 \mathrm{~min}$ at $72{ }^{\circ} \mathrm{C}$ (Abdelkafi et al., 2006b; Ben Ali Gam et al., 2007). PCR products were then cloned into pGEM-T-easy (Promega) according to the manufacturer's protocol. Recombinant clones with inserts of the expected size were sequenced by using the vector-specific primers SP6 (5'-ATTTAGGTGACACTATAGAA- $\left.3^{\prime}\right)$ and T7 (5'-TAATACGACTCACTATAGGG-3') (Genome Express). Plasmids containing inserts of the expected size were isolated using a Wizard Plus SV Minipreps DNA purification system (Promega), according to the manufacturer's protocol. Purified plasmids were sent for sequencing to GATC (Konstanz, Germany). Sequence data were imported into the sequence editor BioEdit version 5.0.9 (Hall, 1999); base calls were examined and a contiguous sequence was obtained. The full sequence was aligned using the RDP version 8 Sequence Aligner program (Maidak et al., 2001) and was adjusted manually to conform to the $16 \mathrm{~S}$ rRNA gene secondary structure model (Lane et al., 1985). A nonredundant BLAST search (Altschul et al., 1997) was used to identify the closest relatives of strain $\mathrm{RB}_{2} 2^{\mathrm{T}}$. Sequences used in the phylogenetic analysis were obtained from RDP Version 8 (Maidak et al., 2001) and GenBank databases (Benson et al., 1999). Positions of sequence and alignment ambiguity were omitted and pairwise evolutionary distances were calculated using the method of Jukes \& Cantor (1969). A dendrogram was constructed using the neighbour-joining method (Saitou \& Nei, 1987). Confidence in the tree topology was determined using 100 bootstrapped trees (Felsenstein, 1985).

After 2 days of incubation at $30{ }^{\circ} \mathrm{C}$ with crude oil, the enrichment culture supported growth. Several strains were isolated from exhaust water of the Tunisian oil refinery in the presence of yeast extract, peptone and lactate as substrates and either sulfate or thiosulfate as terminal electron acceptor.

Amongst the strains isolated from exhaust water of the Tunisian oil refinery, four strains (RB21, RB22 ${ }^{\mathrm{T}}$, API4T and API2B) were found to belong to the genus Desulfovibrio. Strains API4T and API2B were found to be closely related to Desulfovibrio senezii DSM $8436^{\mathrm{T}}$ (Tsu et al., 1998), with $99.9 \%$ 16S rRNA gene sequence similarity. The closest phylogenetic relative of strains $\mathrm{RB}_{2}{ }^{\mathrm{T}}$ and RB21 was Desulfovibrio aespoeensis DSM $10631^{\mathrm{T}}$ (Motamedi \& Pedersen, 1998), but with low $16 \mathrm{~S}$ rRNA gene sequence similarity $(<97 \%)$. The gene sequence similarity of strain $\mathrm{RB} 22^{\mathrm{T}}$ with $D$. aespoeensis DSM $10631^{\mathrm{T}}$ was determined to be $94.6 \%$. These results indicated that strains RB21 and $\mathrm{RB} 22^{\mathrm{T}}$ could represent a novel species of the genus Desulfovibrio. Strain $\mathrm{RB} 22^{\mathrm{T}}$ was chosen as the type strain and was characterized further. 
Cells of strain $\mathrm{RB} 22^{\mathrm{T}}$ were Gram-negative and spores were never observed. Strain RB22 ${ }^{\mathrm{T}}$ was mesophilic and strictly anaerobic. Cells were vibrio-shaped or sigmoid, $0.5 \times 1$ $2.5 \mu \mathrm{m}$, and occurred singly or in chains. For the determination of the $\mathrm{NaCl}$ requirement, various amounts of $\mathrm{NaCl}$ were weighed directly in tubes, prior to dispensing $\mathrm{NaCl}$-free enrichment medium, to obtain $\mathrm{NaCl}$ concentrations of 0-200 $\mathrm{g} \mathrm{l}^{-1}$ (Abdelkafi et al., 2006a; Ben Ali Gam et al., 2007). The isolate was regarded as being a weakly halotolerant bacterium and grew in the presence of $\mathrm{NaCl}$ concentrations ranging from 0 to $70 \mathrm{~g} \mathrm{l}^{-1}$, with optimum growth occurring at $40 \mathrm{~g} \mathrm{NaCl} \mathrm{l}^{-1}$. Strain $\mathrm{RB}_{2} 2^{\mathrm{T}}$ did not require $\mathrm{NaCl}$ for growth. For $\mathrm{pH}$ studies, the medium was adjusted to the desired $\mathrm{pH}$ using anaerobically prepared stock solutions of $\mathrm{NaHCO}_{3}(10 \%)$ or $\mathrm{Na}_{2} \mathrm{CO}_{3}(10 \%)$. The optimum $\mathrm{pH}$ for growth was 7.0 and growth occurred between $\mathrm{pH} 4.5$ and 9. The optimum temperature for

Table 1. Differential physiological and biochemical characteristics of strains RB22 ${ }^{\top}$ (Desulfovibrio tunisiensis sp. nov.), $D$. halophilus DSM $5663^{\top}$ and ' $D$. brasiliensis' DSM 15816

Data for D. halophilus DSM 5663 ${ }^{\mathrm{T}}$ and 'D. brasiliensis' DSM 15816 were taken from Caumette et al. (1991) and Warthmann et al. (2005), respectively. Data for strain $\mathrm{RB} 22^{\mathrm{T}}$ were from this study. ND, Not determined.

\begin{tabular}{|c|c|c|c|}
\hline Characteristic & $\begin{array}{l}\text { Strain } \\
\mathrm{RB}^{2} 2^{\mathrm{T}}\end{array}$ & $\begin{array}{l}\text { D. halophilus } \\
\text { DSM } 5663^{T}\end{array}$ & $\begin{array}{c}\text { 'D. brasiliensis' } \\
\text { DSM } 15816\end{array}$ \\
\hline \multicolumn{4}{|l|}{$\begin{array}{l}\text { Temperature for } \\
\text { growth }\left({ }^{\circ} \mathrm{C}\right)\end{array}$} \\
\hline Range & $15-45$ & $17-42$ & $15-45$ \\
\hline Optimum & 37 & 35 & 33 \\
\hline \multicolumn{4}{|l|}{$\mathrm{pH}$ for growth } \\
\hline Range & $4.5-9$ & $5.5-8.5$ & $6.3-9.0$ \\
\hline Optimum & 7.0 & 7.0 & 7.6 \\
\hline \multicolumn{4}{|l|}{$\begin{array}{l}\mathrm{NaCl} \text { concentration } \\
\text { for growth }(\%)\end{array}$} \\
\hline Range & $0-7$ & $3-18$ & $1-15$ \\
\hline Optimum & 4 & $6-7$ & $3-10$ \\
\hline \multicolumn{4}{|l|}{$\begin{array}{l}\text { Electron donors (with } \\
\text { either sulfate or } \\
\text { thiosulfate) }\end{array}$} \\
\hline Malate & - & - & + \\
\hline Butanol & - & - & ND \\
\hline Ethanol & - & + & - \\
\hline Fumarate & + & - & + \\
\hline Formate & + & $\mathrm{ND}$ & + \\
\hline Methanol & + & ND & - \\
\hline \multicolumn{4}{|l|}{$\begin{array}{l}\text { Electron acceptors } \\
\text { (with lactate as } \\
\text { energy and carbon } \\
\text { source) }\end{array}$} \\
\hline Fumarate & - & - & + \\
\hline Thiosulfate & + & + & - \\
\hline $\begin{array}{l}\text { DNA G }+ \text { C content } \\
(\mathrm{mol} \%)\end{array}$ & 59.6 & 60.7 & 56.3 \\
\hline
\end{tabular}

growth was $37{ }^{\circ} \mathrm{C}$ (temperature range for growth was $15-$ $\left.45{ }^{\circ} \mathrm{C}\right)$.

Substrate utilization tests were performed with modified enrichment medium (i.e. without crude oil and peptone, with $0.1 \mathrm{~g}$ yeast extract and with either sulfate or thiosulfate as a terminal electron acceptor).

Strain $\mathrm{RB}_{22}{ }^{\mathrm{T}}$ utilized the following substrates $(20 \mathrm{mM})$ as carbon and energy sources: lactate, $\mathrm{H}_{2}+\mathrm{CO}_{2}(80: 20$, v/v; 2 bars), formate, fumarate, succinate, glycerol and methanol. Acetate, malate, propionate, ethanol, butanol and 2propanol were also tested but did not support growth. Sulfate $(20 \mathrm{mM})$, thiosulfate $(20 \mathrm{mM})$, elemental sulfur $(1 \%, \mathrm{w} / \mathrm{v})$, sulfite $(2 \mathrm{mM})$ and bisulfite $(0.1 \%, \mathrm{w} / \mathrm{v})$ were used as terminal electron acceptors, but not fumarate, nitrate or nitrite $(10 \mathrm{mM})$. The presence of bisulfite reductase (desulfoviridin) was confirmed by measuring the absorbance of cell-free extracts at $630 \mathrm{~nm}$ (Badziong et al., 1978). In addition, $c$-type cytochromes were detected by reduction of extracts with sodium dithionite, with two peaks occurring at 418 and $550 \mathrm{~nm}$.

Other characteristics of strain RB22 $2^{\mathrm{T}}$, in comparison with those of closely related species of the genus Desulfovibrio, are shown in Table 1 and were determined as described previously (George et al., 2008; Alazard et al., 2003).

The $\mathrm{G}+\mathrm{C}$ content of the genomic DNA of strain RB22 ${ }^{\mathrm{T}}$ was $59.6 \mathrm{~mol} \%$, as determined by using the HPLC method (Mesbah et al., 1989). This value fell within the range described for species of the genus Desulfovibrio (Claus \& Berkeley, 1986).

Phylogenetic analyses, based on 16S rRNA gene sequence data, indicated that strain $\mathrm{RB} 22^{\mathrm{T}}$ was most closely related to species of the genus Desulfovibrio (Fig. 1). Strain RB22 ${ }^{\mathrm{T}}$ exhibited levels of $16 \mathrm{~S}$ rRNA gene similarity of 94.6, 94.12, 93.88 and $93.69 \%$ to the type strains of $D$. aespoeensis, Desulfovibrio dechloracetivorans, 'Desulfovibrio caledoniensis' and D. halophilus, respectively. Levels of $16 \mathrm{~S}$ rRNA gene similarity between strain $\mathrm{RB} 22^{\mathrm{T}}$ and other strains used in the phylogenetic analysis were less than $95 \%$. The generally recommended and accepted criteria for delineating bacterial species state that strains with 16S rRNA gene sequence similarities of less than $97 \%$ do not belong to the same species (Stackebrandt et al., 2002; Wayne et al., 1987), with no need for DNA-DNA relatedness studies.

\section{Description of Desulfovibrio tunisiensis sp. nov.}

Desulfovibrio tunisiensis (tu.ni.si.en'sis. N.L. masc. adj. tunisiensis of Tunisia, pertaining to Tunisia).

Cells are strictly anaerobic, motile, vibrio-shaped or sigmoid, $0.5 \times 1-2.5 \mu \mathrm{m}$, and occurr singly and in chains. Grows at $15-45{ }^{\circ} \mathrm{C}$, with optimum growth at $37{ }^{\circ} \mathrm{C}$. Grows in the presence of $\mathrm{NaCl}$ at $0-7 \%(\mathrm{w} / \mathrm{v})$, with optimum growth around $4 \%$. Optimum $\mathrm{pH}$ for growth is 7.0 ; growth occurs at $\mathrm{pH}$ 4.5-9. Utilizes $\mathrm{H}_{2}+\mathrm{CO}_{2}$, formate, fumarate, lactate, succinate, glycerol and methanol as electron donors. 


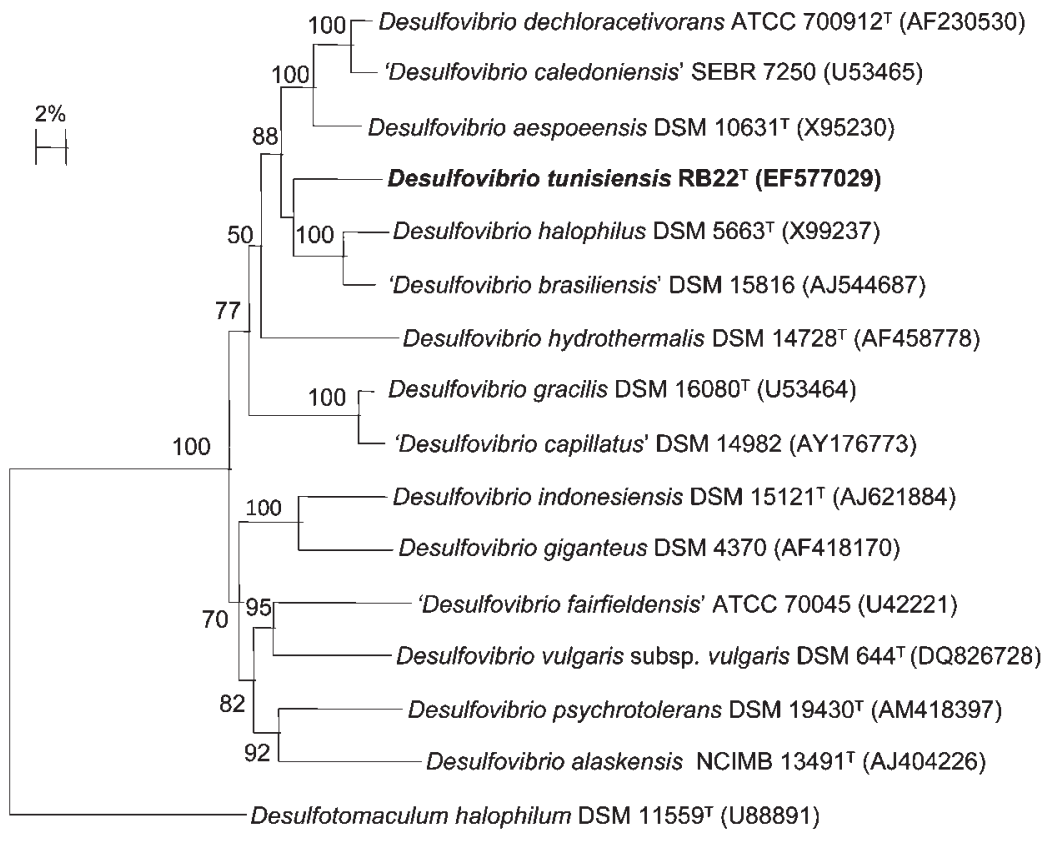

Fig. 1. Phylogenetic dendrogram based on 1347 unambiguous bp of 16S rRNA gene sequences indicating the position of strain $\mathrm{RB}^{2} 2^{\top}$ and closely related species of the genus Desulfovibrio. The tree was constructed using the neighbour-joining algorithm. Accession numbers are given in parentheses. Bar, 0.02 substitutions per nucleotide position.
Lactate is converted to acetate. Substrates that are not utilized include acetate, malate, benzoate, propionate, ethanol, butanol, 2-propanol, glucose and peptone. Fumarate and pyruvate are fermented. Utilizes elemental sulfur, sulfate, thiosulfate and sulfite but not fumarate, nitrate or nitrite as electron acceptors. Desulfoviridin and $c$ type cytochromes are present. The $\mathrm{G}+\mathrm{C}$ content of the DNA of the type strain is $59.6 \mathrm{~mol} \%$ (HPLC).

The type strain, strain $\mathrm{RB} 22^{\mathrm{T}}\left(=\mathrm{NCIMB} 14400^{\mathrm{T}}=\mathrm{JCM}\right.$ $\left.15076^{\mathrm{T}}=\mathrm{DSM} 19275^{\mathrm{T}}\right)$, was isolated from exhaust water of a Tunisian oil refinery.

\section{Acknowledgements}

Z. Ben Ali Gam would like to thank the Ministry of Research and Technologies of Tunisia for his PhD fellowship.

\section{References}

Abdelkafi, S., Labat, M., Casalot, L., Chamkha, M. \& Sayadi, S. (2006a). Isolation and characterization of Halomonas sp. strain IMPC, a $p$-coumaric acid-metabolising bacterium that decarboxylates other cinnamic acids under hypersaline conditions. FEMS Microbiol Lett 255, 108-114.

Abdelkafi, S., Sayadi, S., Ben Ali Gam, Z., Casalot, L. \& Labat, M. (2006b). Bioconversion of ferulic acid to vanillic acid by Halomonas elongata isolated from table-olive fermentation. FEMS Microbiol Lett 262, 115-120.

Abildgaard, L., Nielsen, M. B., Kjeldsen, K. U. \& Ingvorsen, K. (2006). Desulfovibrio alkalitolerans sp. nov., a novel alkalitolerant, sulfatereducing bacterium isolated from district heating water. Int J Syst Evol Microbiol 56, 1019-1024.

Alazard, D., Dukan, S., Urios, A., Verhé, F., Bouabida, N., Morel, F., Thomas, P., Garcia, J.-L. \& Ollivier, B. (2003). Desulfovibrio hydrothermalis sp. nov., a novel sulfate-reducing bacterium isolated from hydrothermal vents. Int J Syst Evol Microbiol 53, 173-178.

Altschul, S. F., Madden, T. L., Schäffer, A. A., Zhang, J., Zhang, Z., Miller, W. \& Lipman, D. J. (1997). Gapped BLAST and PSI-BLAST: a new generation of protein database search programs. Nucleic Acids Res 25, 3389-3402.

Badziong, W., Thauer, R. K. \& Zeikus, J. G. (1978). Isolation and characterization of Desulfovibrio growing on hydrogen plus sulfate as the sole energy source. Arch Microbiol 116, 41-49.

Balch, W. E., Fox, G. E., Magrum, L. J., Woese, C. R. \& Wolfe, R. S. (1979). Methanogens: reevaluation of a unique biological group. Microbiol Rev 43, 260-296.

Ben Ali Gam, Z., Abdelkafi, S., Casalot, L., Tholozan, J.-L., Oueslati, R. \& Labat, L. (2007). Modicisalibacter tunisiensis gen. nov., sp. nov., an aerobic moderately halophilic bacterium isolated from an oilfield water, and emended description of the family Halomonadaceae. Int $\mathrm{J}$ Syst Evol Microbiol 57, 2307-2313.

Ben Dhia-Thabet, O., Fardeau, M. L., Suarez-Nuñez, C., Hamdi, M., Thomas, P., Ollivier, B. \& Alazard, D. (2007). Desulfovibrio marinus sp. nov., a moderately halophilic sulfate-reducing bacterium isolated from marine sediments in Tunisia. Int J Syst Evol Microbiol 57, 2167 2170.

Benson, D. A., Boguski, M. S., Lipman, D. J., Ostell, J., Ouellette, B. F. F., Rapp, B. A. \& Wheeler, D. L. (1999). GenBank. Nucleic Acids Res 27, 12-17.

Birkeland, N. K. (2005). Sulfate-reducing bacteria and archaea. In Petroleum Microbiology, pp. 35-54. Edited by B. Ollivier \& M. Magot. Washington, DC: American Society for Microbiology.

Caumette, P., Cohen, Y. \& Matheron, R. (1991). Isolation and characterization of Desulfovibrio halophilus sp. nov., a halophilic sulfate-reducing bacterium isolated from solar lake (Sinai). Syst Appl Microbiol 14, 33-38.

Claus, D. \& Berkeley, R. C. W. (1986). Genus Bacillus Cohn 1872. In Bergey's Manual of Systematic Bacteriology, vol. 2, pp. 1105-1140. Edited by P. H. A. Sneath, N. S. Mair, M. E. Sharpe \& J. G. Holt. Baltimore: Williams \& Wilkins. 
Cord-Ruwisch, R. (1985). A quick method for the determination of dissolved and precipitated sulphides in cultures of sulfate-reducing bacteria. J Microbiol Methods 4, 33-36.

Dang, P. N., Dang, T. C. H., Lai, T. H. \& Stan-Lotter, H. (1996). Desulfovibrio vietnamensis sp. nov., a halophilic sulfate-reducing bacterium from Vietnamese oil fields. Anaerobe 2, 385-392.

Feio, M. J., Beech, I. B., Carepo, M., Lopes, J. M., Cheug, C. W. S., Franco, R., Guezennec, J., Smith, J. R., Mitchell, J. I. \& other authors (1998). Isolation and characterisation of a novel sulfate-reducing bacterium of the Desulfovibrio genus. Anaerobe 4, 117-130.

Feio, M. J., Zinkevich, V., Beech, I. B., Llobet-Brossa, E., Eaton, P., Schmitt, J. \& Guezennec, J. (2004). Desulfovibrio alaskensis sp. nov., a sulphate-reducing bacterium from a soured oil reservoir. Int J Syst Evol Microbiol 54, 1747-1752.

Felsenstein, J. (1985). Confidence limits on phylogenies: an approach using the bootstrap. Evolution 39, 783-791.

George, J., Purushothaman, C. S. \& Shouche, Y. S. (2008). Isolation and characterization of sulfate-reducing bacteria Desulfovibrio vulgaris from Vajreshwari thermal springs in Maharashtra, India. World $J$ Microbiol Biotechnol 24, 681-685.

Hall, T. A. (1999). BioEdit: a user-friendly biological sequence alignment editor and analysis program for Windows 95/98/NT. Nucleic Acids Symp Ser 41, 95-98.

Hamilton, W. A. (1985). Sulfate-reducing bacteria and anaerobic corrosion. Annu Rev Microbiol 39, 195-217.

Haouari, O., Fardeau, M. L., Casalot, L., Tholozan, J. L., Hamdi, M. \& Ollivier, B. (2006). Isolation of sulfate-reducing bacteria from Tunisian marine sediments and description of Desulfovibrio bizertensis sp. nov. Int J Syst Evol Microbiol 56, 2909-2913.

Hungate, R. E. (1969). A roll tube method for cultivation of strict anaerobes. Methods Microbiol 3B, 117-132.

Jukes, T. H. \& Cantor, C. R. (1969). Evolution of protein molecules. In Mammalian Protein Metabolism, vol. 3, pp. 21-132. Edited by H. N. Munro. New York: Academic Press.

Lane, D. J., Pace, B., Olsen, G. J., Stahl, D. A., Sogin, M. L. \& Pace, N. R. (1985). Rapid determination of $16 \mathrm{~S}$ ribosomal RNA sequences for phylogenetic analyses. Proc Natl Acad Sci U S A 82, 6955-6959.

Magot, M., Caumette, P., Desperrier, J. M., Matheron, R., Dauga, C., Grimont, F. \& Carreau, L. (1992). Desulfovibrio longus sp. nov., a sulfate-reducing bacterium isolated from an oil-producing well. Int $J$ Syst Bacteriol 42, 398-403.

Magot, M., Basso, O., Tardy-Jacquenod, C. \& Caumette, P. (2004). Desulfovibrio bastinii sp. nov. and Desulfovibrio gracilis sp. nov., moderately halophilic, sulfate-reducing bacteria isolated from deep subsurface oilfield water. Int J Syst Evol Microbiol 54, 1693-1697.

Maidak, B. L., Cole, J. R., Lilburn, T. G., Parker, C. T., Jr, Saxman, P. R., Farris, R. J., Garrity, G. M., Olsen, G. J., Schmidt, T. M. \& Tiedje, J. M.
(2001). The RDP-II (Ribosomal Database Project). Nucleic Acids Res 29, 173-174.

Mesbah, M., Premachandran, U. \& Whitman, W. B. (1989). Precise measurement of the $\mathrm{G}+\mathrm{C}$ content of deoxyribonucleic acid by highperformance liquid chromatography. Int J Syst Bacteriol 39, 159-167.

Miranda-Tello, E., Fardeau, M.-L., Cayol, J.-L., Thomas, P., Ostoa, P., Ramírez, F., Fernández, L., Garcia, J.-L. \& Ollivier, B. (2003). Desulfovibrio capillatus sp. nov., a long-chained sulfate-reducing bacterium isolated from Gulf of Mexico oil well. Anaerobe 9, 97-103.

Motamedi, M. \& Pedersen, K. (1998). Desulfovibrio aespoeensis sp. nov., a mesophilic sulfate-reducing bacterium from deep groundwater at Aspo hard rock laboratory, Sweden. Int J Syst Bacteriol 48, 311-315.

Reichenbecher, W. \& Schink, B. (1997). Desulfovibrio inopinatus, sp. nov., a new sulfate-reducing bacterium that degrades hydroxyhydroquinone (1,2,4-trihydroxybenzene). Arch Microbiol 168, 338-344.

Saitou, N. \& Nei, M. (1987). The neighbor-joining method: a new method for reconstructing phylogenetic trees. Mol Biol Evol 4, 406425.

Stackebrandt, E., Frederiksen, W., Garrity, G. M., Grimont, P. A., Kämpfer, P., Maiden, M. C., Nesme, X., Rosselló-Mora, R., Swings, J. \& other authors (2002). Report of the ad hoc committee for the reevaluation of the species definition in bacteriology. Int J Syst Evol Microbiol 52, 1043-1047.

Tardy-Jacquenod, C., Magot, M., Laigret, F., Patel, B. K. C., Guezennec, J., Matheron, R. \& Caumette, P. (1996). Desulfovibrio gabonensis sp. nov., a new moderately halophilic, sulfate-reducing bacterium isolated from an oil pipeline. Int J Syst Bacteriol 46, 710715 .

Tsu, I. H., Huang, C. Y., Garcia, J.-L., Patel, B. K. C., Cayol, J. L., Baresi, L. \& Mah, R. A. (1998). Isolation and characterization of Desulfovibrio senezii sp. nov., a halotolerant sulfate reducer from a solar saltern and phylogenetic confirmation of Desulfovibrio fructosovorans as a new species. Arch Microbiol 170, 313-317.

Vandieken, V., Knoblauch, C. \& Jørgensen, B. B. (2006). Desulfovibrio frigidus sp. nov. and Desulfovibrio ferrireducens sp. nov., psychrotolerant bacteria isolated from Arctic fjord sediments (Svalbard) with the ability to reduce Fe(III). Int J Syst Evol Microbiol 56, 681-685.

Warthmann, R., Vasconcelos, C., Sass, H. \& McKenzie, J. A. (2005). Desulfovibrio brasiliensis sp. nov., a moderate halophilic sulfatereducing bacterium from Lagoa Vermelha (Brazil) mediating dolomite formation. Extremophiles 9, 255-261.

Wayne, L. G., Brenner, D. J., Colwell, R. R., Grimont, P. A. D., Kandler, O., Krichevsky, M. I., Moore, L. H., Moore, W. E. C., Murray, R. G. E. \& other authors (1987). International Committee on Systematic Bacteriology. Report of the ad hoc committee on reconciliation of approaches to bacterial systematics. Int J Syst Bacteriol 37, 463-464. 